Preparing for 1979

A Special Correspondent reports on preparations for the United Nations Conference on Science and Technology

THE appointment in January of $\mathrm{Mr}$ Joao Frank da Costa of Brazil as Secretary-General of the United Nations Conference on Science and Technology, which is scheduled for 1979, has enabled preparations to get under way. Sitting as the Preparatory Committee for the Conference, the 54nation Committee on Science and Technology for Development gave a mixed reception to $\mathrm{Mr}$ da Costa's views on the organisation and timing of the conference preparations. He secured agreement, however, on several vital points, the most important of which is perhaps that he should have as free a hand as possible in the selection of the conference secretariat.

Kurt Waldheim, the UN SecretaryGeneral, had stated that the post of Deputy Secretary-General of the Conference should be held by $\mathrm{Dr}$ KlausHeinrich Standke, the Director of the Office of Science and Technology in New York, and that his staff should form the core of the conference secretariat. From the first, $\mathrm{Mr}$ da Costa made it clear that he could not accept this arrangement, especially as Dr Standke was expected to double up two responsible jobs from now until the conference. No deputy as such has been appointed; the Executive Secretary of the Conference, Mr Hans Einhaus, who has lately represented the Office of Science and Technology in Geneva, is holding this position in an acting capacity.
Da Costa was less successful in persuading the committee of the practicability of some of his other ideas, such as the suggestion that each member state should produce three preparatory documents for the conference. If previous performance is anything to go by, many governments will have difficulty in producing a single really useful paper, as now requested, although the option to produce more remains open for those who can. Regional papers will also be prepared by the several UN Economic Commissions. With those from the other members of the UN system and from major organisations outside the UN, these will make up a considerable amount of documentation. To offset this, the number of meetings, seminars and so on suggested for the preparatory period will be reduced; the suggestion that the conference secretariat should be regionalised was also dropped.

No precise agenda is expected until this time next year, but the general objectives of the conference are already well defined. They include: the adoption of concrete decisions on ways of applying science and technology, as a strategy aimed at economic and social development "within a time frame"; strengthening the technological capacity of the developing countries; the adoption of means for the utilisation of science and technology in solving the problems of development; and the provision of "instruments of cooperation" to developing countries, for solving socio-economic problems that cannot be solved by individual action.

In general, it does seem as though the agenda will be action-oriented; one thing da Costa stressed was the need to avoid the "ritual complications" inherent in the preparations for all such conferences-the ritual of producing documents and of setting-up institutions do not of themselves solve problems, but are only tools to that end. In general, the objective of the conference will be to assess and redefine the role that science and technology has to play in development. Moreover, as seen by da Costa the preparations themselves can help towards the definition of a unified policy for science and technology within the United Nations system.

One other point on which da Costa did not get his way was in the location of the conference secretariat. He had asked that it be set up in Geneva, but this was overruled, the majority of delegations preferring New York, where they can oversee, if not interfere in, the conference preparations. Many regard this as unfortunate. One of the reasons for the success of the Environment Conference in 1972 was the insistence of Maurice Strong, as Secretary-General, that his headquarters should be in Geneva, away from the UN bureaucracy.

The New York siting could also prejudice really close collaboration on the part of the other members of the system, although their involvement has been one of the avowed intentions of those who suggested the conference in the first place. Geneva is central to these organisations-UNESCO in Paris, UNIDO and IAEA in Vienna, FAO in Rome and, in Geneva itself, WHO, WMO, UNCTAD and ILO. It is in these organisations that the bulk of international knowledge and experience in applying science and technology lies, and the possible economies of having the secretariat in New York may well be offset by a loss of their close collaboration and good will.

\section{Support for alternatives}

David Spurgeon reports from Ottawa on Canada's interest in alternative energy sources

Canada, a country once thought to possess fabulous natural gas and petroleum supplies, is now carefully assessing its renewable energy resources. The government has recently increased the funds available for research on tidal power, wind power, biomass and solar energy. And the whole subject was highlighted at a recent meeting of the Parliamentary and Scientific Committee sponsored by SCITEC, the Association of the Scientific, Engineering and Technological Community of Canada. It was the second meeting of the committee, which was formed to bring parliamentarians and scientists together, and in spite of scepticism that this could be done, both meetings were well attended.

One of the most interesting energy potentials discussed was the Bay of
Fundy's tidal power. Separating the two Maritime provinces of Nova Scotia and New Brunswick, the Bay of Fundy possesses one of the world's largest tide ranges. A. N. Karas, assistant director of planning for the Electrical Engineering Branch of the National Energy Board, said that although the last detailed study in 1968 concluded that Fundy power projects were uneconomic (albeit feasible), significant increases in power generation costs had helped the two provincial governments and the federal government to agree in 1975 to re-evaluate such schemes.

The conclusion was that the combined market for a $7,000 \mathrm{MW}$ tidal 